\title{
Effects of human trampling on a rocky shore fauna on the Sao Paulo coast, southeastern Brazil
}

\author{
Ferreira, MN.* and Rosso, $S . *$ \\ Departamento de Ecologia, Insituto de Biociências, Universidade de São Paulo - USP, \\ Rua do Matão, Travessa 14, 321, CEP 05508-900, São Paulo, SP, Brazil \\ *e-mail: marinf@ib.usp.br, serrosso2@ib.usp.br \\ Received January 28, 2008 - Accepted June 25, 2008 - Distributed November 30, 2009
}

(With 6 figures)

\begin{abstract}
Increased tourist activity in coastal regions demands management strategies to reduce impacts on rocky shores. The highly populated coastal areas in southeastern Brazil are an example of degradation caused by development of industry and tourism. Among different shore impacts, trampling has been intensively studied, and may represent a significant source of stress for intertidal fauna. A randomised blocks design was applied to experimentally study the effects of two different trampling intensities on richness, diversity, density and biomass of the rocky shore fauna of Obuseiro beach, Guarujá, southeastern Brazil. Blocks were distributed in two portions of the intertidal zone, dominated respectively by Chthamalus bisinuatus (Cirripedia) and Isognomon bicolor (Bivalvia). Blocks were trampled over three months, simulating the vacation period in Brazil and were monitored for the following nine months. Results indicate that Chthamalus bisinuatus is vulnerable to trampling impacts. Richness, diversity and turn-over index tended to be higher in trampled plots four months after trampling ceased. In general, results agree with previous trampling studies, suggesting that even low intensities of trampling may cause some impact on intertidal communities. Management strategies should include isolation of sensitive areas, construction of boardwalks, visitor education and monitoring programmes. In Brazil, additional data obtained from experimental studies are necessary in order to achieve a better understanding of trampling impacts on rocky shore communities.
\end{abstract}

Keywords: rocky shore, intertidal community, trampling, tourism impacts.

\section{Impactos do pisoteio humano na fauna de um costão rochoso do litoral de São Paulo, no sudeste brasileiro}

\begin{abstract}
Resumo
O aumento da atividade turística em áreas costeiras nas últimas décadas faz necessária a adoção de estratégias de manejo para reduzir os impactos gerados às comunidades de costões rochosos. A região costeira do sudeste brasileiro possui bons exemplos de degradação causada pelo turismo e desenvolvimento industrial. Dentre os diferentes distúrbios causados pela visitação, o pisoteio têm sido estudado de forma intensa e pode representar uma fonte significativa de impactos para as comunidades da zona entre-marés. Neste projeto, foi aplicado um desenho de blocos randômicos para se avaliar experimentalmente os efeitos de duas intensidades de pisoteio na riqueza, diversidade, densidade, recobrimento e biomassa da fauna de um costão situado na praia do Obuseiro, no município do Guarujá, São Paulo, Brasil. Os blocos foram alocados em dois povoamentos diferentes, dominados respectivamente por Chthamalus bisinuatus (Cirripedia) e Isognomon bicolor (Bivalvia). O pisoteio foi aplicado durante três meses, simulando a temporada de férias no Brasil, e os blocos foram monitorados nos nove meses seguintes. Os resultados indicaram que Chthamalus bisinuatus é vulnerável aos impactos do pisoteio. Os índices de riqueza, diversidade e turnover apresentaram uma tendência ao aumento nas áreas pisoteadas quatro meses após o término do pisoteio. No geral, os resultados concordam com estudos anteriores e sugerem que mesmo baixas intensidades do distúrbio podem causar impacto às comunidades bentônicas. Estratégias de manejo devem envolver o isolamento de áreas sensíveis, a construção de passarelas, a educação dos visitantes e o monitoramento das comunidades impactadas. No Brasil, a realização de maior quantidade de estudos experimentais é necessária para a melhor compreensão dos impactos do pisoteio nas comunidades de costões rochosos.
\end{abstract}

Palavras-chave: costão rochoso, comunidades intertidais, pisoteio, impactos turísticos. 


\section{Introduction}

Rocky shores are subject to increasing anthropogenic impacts originating from both the land and the sea. These habitats have been, and are currently, affected by pollution, over-collection of living resources, introduction of alien species, modification of coastal processes and global changes (Thompson et al., 2002).

Increased tourist activity may also represent a significant source of impact to rocky shore communities. The effects of human trampling on intertidal fauna have been intensively studied, especially in temperate zones (Povey and Keough, 1991; Brosnan and Crumrine, 1994; Fletcher and Frid, 1996; Keough and Quinn, 1998; Schiel and Taylor, 1999). Most studies have observed a reduction in abundance of some taxa, such as polychaetes (Brown and Taylor, 1999), bivalves (Beauchamp and Gowing, 1982) and barnacles (Brosnan and Crumrine, 1994) that may affect population dynamics and diversity of the entire community.

Different species of non-crustose algae were also vulnerable to trampling, showing reduction in values of abundance, cover and biomass (Povey and Keough, 1991; Fletcher and Frid, 1996; Keough and Quinn, 1998; Schiel and Taylor, 1999). Some groups, such as limpets and crustose algae, indirectly benefited from trampling, usually occupying empty areas created after the displacement of conspicuous species (Keough and Quinn, 1998).

Few studies have been developed on barnacle and bivalve assemblages, even though organisms in these groups are considered vulnerable to trampling, since they are small, sessile and easily squashed (Povey and Keough, 1991). Previous research has mostly focused on large conspicuous organisms, even though smaller cryptic animals also deserve attention due to their great abundance, high productivity and importance as food for higher trophic levels (Brown and Taylor, 1999).

The presence of beaches and other natural resources on practically the whole Brazilian coast attracts large number of tourists, especially at vacation periods and close to major cities, such as Sao Paulo. Guaruja municipality, for instance, has a population close to 230,000 people and receives more than 150,000 tourists during the summer season (IBGE, 2002).

The highly populated coastal areas in Brazil are an example of degradation caused by development of industry and tourism with several environmental impacts on coastal communities. However, the effects of human trampling on Brazilian rocky shores have not been previously examined. Therefore, this study aimed to investigate the effects of trampling on communities associated to Chthamalus bisinuatus Pilsbry (Cirripedia) and Isognomon bicolor (Adams) (Bivalvia) from a rocky shore in southeastern Brazil.

\section{Material and Methods}

\subsection{Study site}

The study was conducted at Obuseiro beach in the city of Guarujá (2402' $19.4^{\prime}$ ' S and $46^{\circ} 17^{\prime} 16.2^{\prime}$ 'W), located on the central coast of São Paulo state, in southeastern Brazil. Obuseiro beach is situated within the limits of a military area (" $1{ }^{\circ}$ Batalhão de Artilharia AntiAérea do Forte dos Andradas", Brazilian Army), and the access to the beach is granted only to some local fishermen.

The study site consists of a gently sloping large granite rock, dominated by Chthamalus bisinuatus on the upper-shore and Isognomon bicolor on the mid-shore.

\subsection{Experimental design}

Ten randomised blocks were equally distributed in two portions of the intertidal zone, dominated respectively by Chthamalus bisinuatus and Isognomon bicolor. Both species were selected for this study since they are conspicuous, perennial and widely distributed on rocky shores in southeastern Brazil. I. bicolor is an exotic species that has been recorded on Brazilian rocky shores for the last ten years, especially in the zone originally occupied by the mussel Perna perna (Linnaeus) that has been over-exploited as a food resource in many areas (Martins, 2000).

Blocks were trampled in a single day over three months, simulating the summer vacation period in Brazil, and were monitored for the following nine months. Data collection was always performed before trampling, so data from the first month relates to community conditions before trampling impacts.

Each block consisted of three experimental units (EU), 4,900 $\mathrm{cm}^{2}$ each, separated by a $20 \mathrm{~cm}$ stripe. In each block, different trampling intensities were applied in the EUs, as follows: treatment 0 (no trampling, control units); treatment 1 (50 steps per month); treatment 2 (250 steps per month). Since the steps were applied randomly in a $4,900 \mathrm{~cm}^{2}$ area and foot size was $200 \mathrm{~cm}^{2}$, it can be considered that on average each portion of EUs was trampled two times in treatment 1 and ten times in treatment 2 . Trampling was performed by a $56 \mathrm{~kg}$ person using rubber-soled shoes.

An area of $900 \mathrm{~cm}^{2}$ within the EU was selected for data collection. The position of this area and the treatment applied in each EU was randomly determined. The remaining portion of the EU in the I. bicolor assemblage blocks was used to perform total removals of individuals present in $100 \mathrm{~cm}^{2}$, every 3 months during one year.

These samples were washed in a $0.5 \mathrm{~mm}$ mesh (GRANUTEST) in order to select macrofaunal organisms only. All organisms were counted after identification to species level, with the exception of Ophiuroidea, Turbellaria, Nemertea and Polychaeta which were identified to higher taxonomic levels.

Different variables were analysed, according to assemblage characteristics. Variables and their collection methods are presented as follows:

i) Cover of $C$. bisinuatus: cover estimates were monthly obtained through photographs taken from nine squares of $100 \mathrm{~cm}^{2}$ for each EU. Photographs were scanned and $C$. bisinuatus 
cover percentage was measured in a central area of $25 \mathrm{~cm}^{2}$, using the software ArcView GIS 3.2 (ESRI, 1999). Therefore, for each EU, C. bisinuatus cover was estimated from a total area of $225 \mathrm{~cm}^{2}$ (nine squares of $25 \mathrm{~cm}^{2}$ ).

ii) Cover of I. bicolor: cover estimates were obtained monthly through the division of the $900 \mathrm{~cm}^{2}$ area in 225 small squares of $4 \mathrm{~cm}^{2}$. Each square was classified from zero to two (zero representing none to $35 \%$ cover of $I$. bicolor, one representing 36 to $70 \%$ cover and 2 representing more than $70 \%$ cover of $I$. bicolor). The sum of these classes (that could vary from 0 to 450 ) was then transformed into a percentage value that indicated the cover percentage of I. bicolor in each EU.

iii)Richness of the community associated with I. bicolor: richness was calculated for each sample $\left(100 \mathrm{~cm}^{2}\right)$, based on the number of taxons (mostly species) present in the sample.

iv) Diversity of the community associated with I. bicolor: Shannon-Wiener diversity index $\left(\mathrm{H}^{\prime}\right)$ was applied in its exponential form $\left(2^{\mathrm{H}^{\prime}}-\right.$ Shannon apparent richness) which represents a good alternative to $\mathrm{H}^{\prime}$ and allows direct comparisons to absolute values of richness.

v) Turnover index of the community associated with I. bicolor: this index represents the sum of community losses and gains over time (Giordano, 2001) and it is calculated with the following formula:

$\mathrm{T}=\mathrm{L} / \mathrm{S}_{\mathrm{Tn}}+\mathrm{G} / \mathrm{S}_{\mathrm{Tn}+1}$

where:

$\mathrm{L}=$ number of taxons present in $\mathrm{T}_{\mathrm{n}}$ and absent in $\mathrm{T}_{\mathrm{n}+1}$ (lost taxons)

$\mathrm{G}=$ number of taxons absent in $\mathrm{T}_{\mathrm{n}}$ and present in $\mathrm{T}_{\mathrm{n}+1}$ (gained taxons)

$\mathrm{S}_{\mathrm{Tn}}=$ number of taxons in $\mathrm{T}_{\mathrm{n}}$ time

$\mathrm{S}_{\mathrm{Tn}+1}=$ number of taxons in $\mathrm{T}_{\mathrm{n}+1}$ time

As the sum of two fractions, the turnover index can vary from zero to two, where zero represents

Table 1. Invertebrate intertidal fauna from a rocky shore in Obuseiro beach, SP, Brazil. Common taxa occured in more than 40 samples, frequent taxa occurred in 20 to 39 samples, and rare taxa occurred in less than 20 samples (total: 60 samples).

\begin{tabular}{|c|c|c|}
\hline Taxon & Class & Occurence \\
\hline Polycladia & Turbellaria & Frequent \\
\hline HOPLONEMERTEA & Enopla & Frequent \\
\hline Fissurella clenchi (Farfante) & Gastropoda & Frequent \\
\hline Collisella subrugosa (d'Orbigny) & Gastropoda & Common \\
\hline Nodilittorina lineolata (d'Orbigny) & Gastropoda & Frequent \\
\hline Stramonita haemastoma (Linnaeus) & Gastropoda & Rare \\
\hline Onchidella indolens (Gould) & Gastropoda & Frequent \\
\hline Perna perna & Bivalvia & Frequent \\
\hline Brachidontes solisianus (d'Orbigny) & Bivalvia & Common \\
\hline Isognomon bicolor & Bivalvia & Common \\
\hline Lasea adansoni (Gmelin) & Bivalvia & Common \\
\hline SYLLIDAE & Polychaeta & Common \\
\hline NEREIDIDAE & Polychaeta & Common \\
\hline CIRRATULIDAE & Polychaeta & Frequent \\
\hline Tetraclita stalactifera (Lamarck) & Cirripedia & Rare \\
\hline Chthamalus bisinuatus & Cirripedia & Rare \\
\hline Pachygrapsus transversus (Gibbes) & Malacostraca & Common \\
\hline ALPHEIDAE & Malacostraca & Rare \\
\hline Elasmopus brasiliensis (Dana) & Amphipoda & Common \\
\hline Elasmopus pectenicrus (Bate) & Amphipoda & Common \\
\hline Hyale nigra (Haswell) & Amphipoda & Common \\
\hline Apohyale media (Dana) & Amphipoda & Rare \\
\hline Apohyale wakabarae (Serejo) & Amphipoda & Common \\
\hline Parhyale hawaiensis (Dana) & Amphipoda & Frequent \\
\hline Gammaropsis togoensis (Schellenberg) & Amphipoda & Rare \\
\hline Clianella castroi (Loyola e Silva) & Isopoda & Common \\
\hline OPHIUROIDEA & Ophiuroidea & Rare \\
\hline
\end{tabular}


the persistence of the same taxa in the community, while two represents the complete substitution of community taxa over time.

To better express the index descriptive value, a negative sign was attributed to the numeric value when the relative loss $\left(\mathrm{L} / \mathrm{S}_{\mathrm{Tn}}\right)$ surpassed the relative gain $\left(\mathrm{G} / \mathrm{S}_{\mathrm{Tn}+1}\right)$.

vi) Density of the macrofauna associated with I. bicolor: taxon density (number of individuals of the taxon/100 $\mathrm{cm}^{2}$ ) was calculated for each collected sample.

\subsection{Analyses}

Considering the small numbers of replicates for each assemblage $(\mathrm{n}=5)$, non-parametric tests were adopted in data analysis. Kruskal-Wallis and Mann-Whitney tests were used in order to identify significant differences between treatments.

Cover data from $C$. bisinuatus and I. bicolor followed repeated measures design and were analysed by a method proposed by Gurevitch and Chester Jr. (1986). The remaining variables were taken from independent samples collected every three months, and therefore could not be classified as repeated measures data.

Density values were analysed for each taxon separately, but only results that indicate some pattern are presented herein.

All data analysis was performed using STATISTICA 6.0 (StatSoft Inc., 2003), SPSS 12.0 (SPSS Inc., 2003) and MVSP 3.12a (KCS, 2000).

\section{Results}

Twenty-seven animal taxa were recorded in the studied assemblages (Table 1). Mean percentage cover of $C$. bisinuatus ranged from 15 to $50 \%$. Trampling effects in $C$. bisinuatus cover were observed after the third month of trampling, especially for treatment 2 (Figure 1).

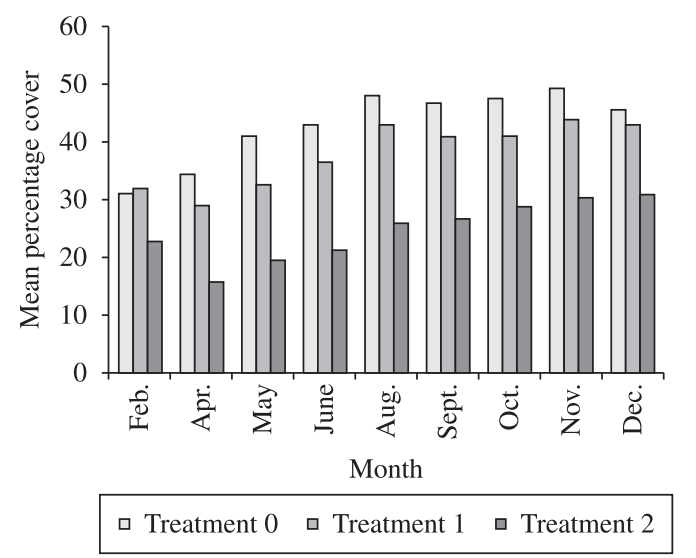

Figure 1. Mean cover percentage of C. bisinuatus over time at all trampling intensities observed at Obuseiro rocky shore, São Paulo, Brazil.
Recovery to original values of differences among treatments (Kruskal-Wallis test; february; $\mathrm{p}=0.0493$ ) was not observed even seven months after trampling ceased (Kruskal-Wallis test; November; $\mathrm{p}=0.004$ ). Repeated measures analysis also indicated that trampling promoted different patterns among treatments (Table 2), but the Tukey HSD test indicated significant differences only between treatments 0 and 2 (Tukey test; $\mathrm{p}=0.0003$ ).

Cover values of $I$. bicolor were usually high, ranging from 75 to $90 \%$ (Figure 2) and were not affected by trampling. However, mean values of percentages decreased with time in all treatments.

Mean richness values of the community associated to I. bicolor ranged from 13 to 18 taxa (Figure 3), while diversity values ranged from 4.5 to 5.8 (Figure 4). Both variables showed similar patterns four months after trampling ceased, with mean values for treatments 1 and 2 significantly higher when compared to original values (Table 3).

For all treatments, the turnover index values declined with time, changing from an initial pattern of gaining species (turnover positive values) to a pattern of losing species (turnover negative values). It is worth noting that while turnover values for treatment 0 were gradually reduced, treatments 1 and 2 values rose from May to August (Figure 5).

Density values varied widely among taxa, ranging from 0.2 to 413 indiviuals $/ 100 \mathrm{~cm}^{2}$. Highest values of

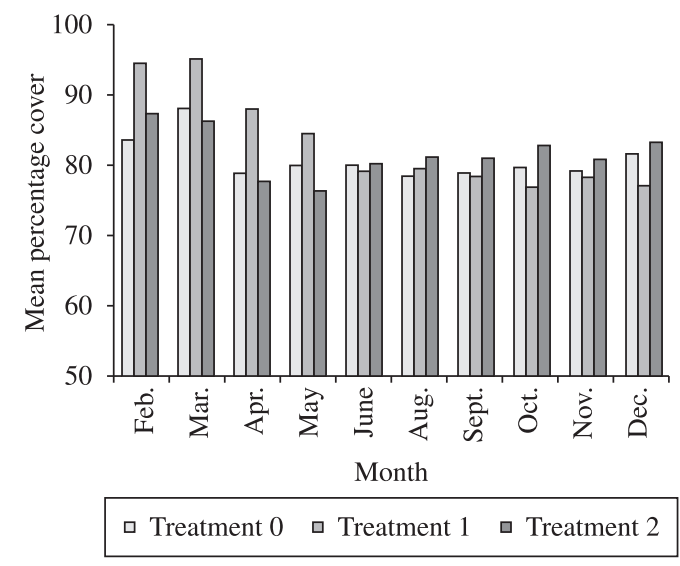

Figure 2. Mean cover percentage of I. bicolor over time at all trampling intensities observed at Obuseiro rocky shore, São Paulo, Brazil.

Table 2. Repeated-measures analysis for $C$. bisinuatus cover.

\begin{tabular}{lrccc}
\hline \multicolumn{1}{c}{ Total } & df & MS & F & p \\
\hline Treatment & 2 & 30030.6 & 22,2970 & 0.000091 \\
Error & 12 & 8081.1 & - & - \\
Total & 14 & - & - & - \\
\hline
\end{tabular}




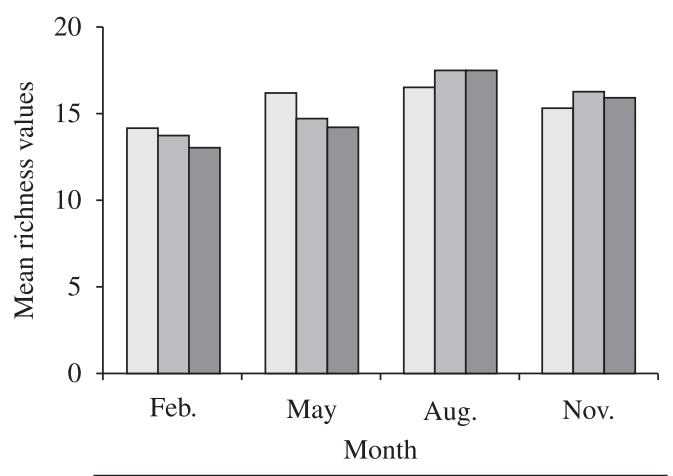

$\square$ Treatment $0 \quad \square$ Treatment $1 \quad \square$ Treatment 2

Figure 3. Mean values of richness of the community associated with $I$. bicolor over time at all trampling intensities observed at Obuseiro rocky shore, São Paulo, Brazil.

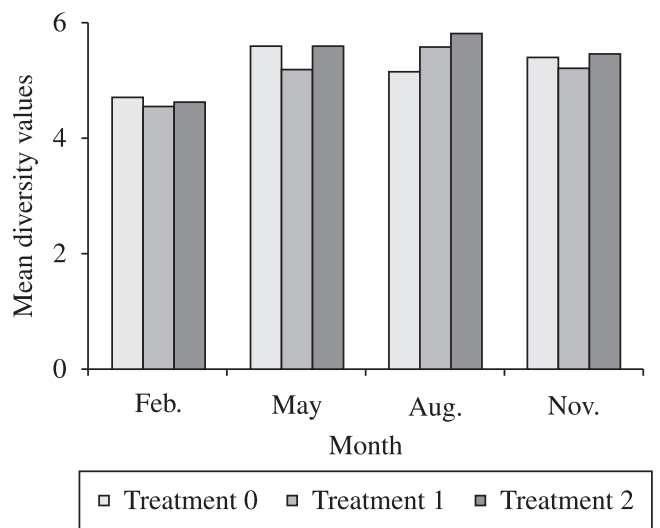

Figure 4. Mean values of diversity of the community associated with I. bicolor over time at all trampling intensities observed at Obuseiro rocky shore, São Paulo, Brazil.

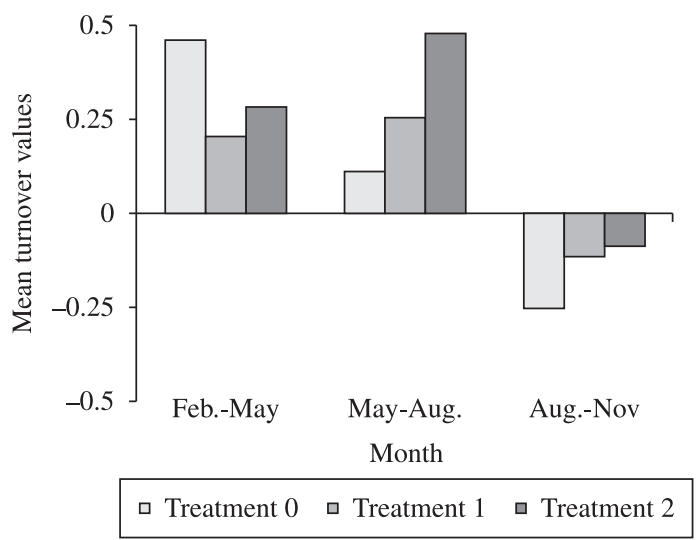

Figure 5. Mean turnover values of the community associated with $I$. bicolor over time at all trampling intensities observed at Obuseiro rocky shore, São Paulo, Brazil.
Table 3. Mann-whitney test results for richness and diversity values of the community associated with I. bicolor $(\mathrm{p}<0.05)$

\begin{tabular}{cccc}
\hline & \multicolumn{4}{c}{ Mann-Whitney (p) } \\
\hline Richness & 0 & $\mathbf{1}$ & $\mathbf{2}$ \\
\hline Feb $\times$ May & 0.2101 & 0.4034 & 0.4034 \\
Feb $\times$ Aug & 0.0947 & 0.0163 & 0.009 \\
Feb $\times$ Nov & 0.5309 & 0.0601 & 0.0601 \\
\hline Diversity & $\mathbf{0}$ & $\mathbf{1}$ & $\mathbf{2}$ \\
\hline Feb $\times$ May & 0.0163 & 0.1172 & 0.1172 \\
Feb $\times$ Aug & 0.1745 & 0.0283 & 0.0283 \\
Feb $\times$ Nov & 0.2506 & 0.1172 & 0.1745 \\
\hline
\end{tabular}

density were presented by I. bicolor, indicating once again its dominance in the assemblage.

Trampling did not affect density values, that varied differently among taxa, but not among treatments. In general, three different patterns were observed: i) density reduction over time, presented by I. bicolor, Brachidontes solisianus, Lasea adansoni and Hyale nigra; ii) density increase over time, presented by Collisella subrugosa; and iii) constant values of density over time, presented by Syllidae polychaetes (Figure 6).

\section{Discussion and Conclusions}

Several studies indicated that invertebrate fauna associated with mussel communities may harbour from 32 to 99 species (Seed, 1996). However, in these studies all taxa were identified to species level, which may be responsible for the higher values found when compared to the I. bicolor community in this study (27 taxa). The structure of the bed may also interfere in these values, since mussel species usually form beds with several layers of individuals (Seed, 1996), increasing attachment and colonization surface for associated species while the I. bicolor bed is constituted by a single layer.

Trampling impacts on $C$. bisinuatus cover may be related to low resistance of individuals to direct effects of trampling. Chthamalus species were also affected by trampling on rocky shores in the United States, Australia and United Kingdom (Povey and Keough, 1991; Brosnan and Crumrine, 1994; Pinn and Rodgers, 2005), suggesting that morphological, physiological or reproductive aspects of the group may be responsible for its high vulnerability to trampling. Moreover, low cover values and indirect effects, such as limpets pasture could have also prevented $C$. bisinuatus recovery after trampling.

Resistance of I. bicolor to trampling may be explained by its high values of density and also by aspects, such as accommodation and lateral movement, that correspond to rapid colonization of small patches by adult individuals (Connell and Keough, 1985).

Increase in richness and diversity values after trampling have already been observed in previous studies 

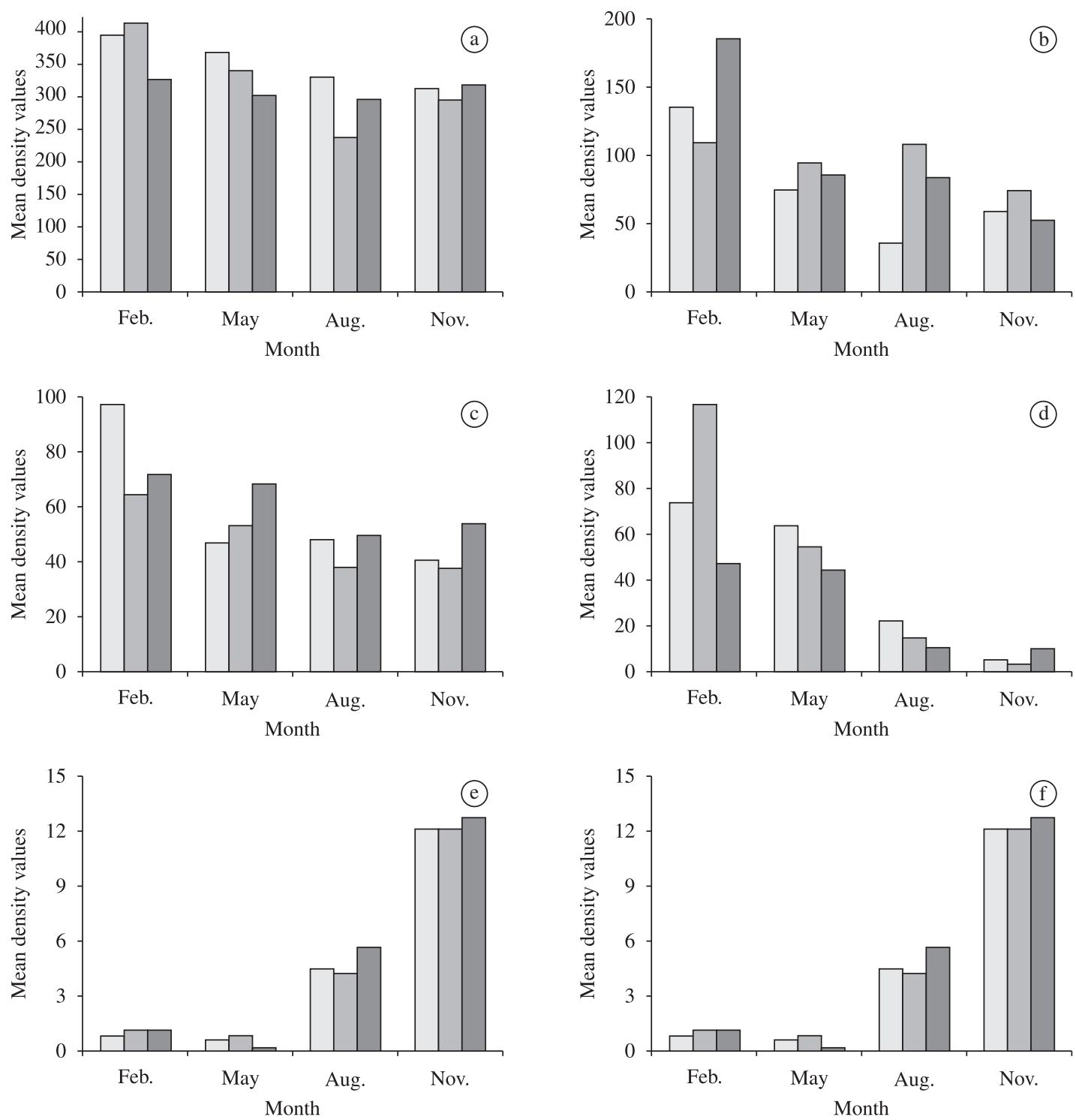

$\square$ Treatment $0 \quad \square$ Treatment $1 \quad \square$ Treatment 2

Figure 6. Mean density values (number of individuals $/ 100 \mathrm{~cm}^{2}$ ) over time of a) I. bicolor, b) Brachidontes solisianus, c) Lasea adansoni, d) Hyale nigra, e) Collisella subrugosa and f) Syllidae from Obuseiro rocky shore, São Paulo, Brazil.

especially for intermediate levels of trampling (Liddle, 1975; Beauchamp and Gowing, 1982).

This pattern follows the disturbance hypothesis proposed by Connell (1978), in which intermediate level perturbations may interfere in the competitive exclusion process, changing community structure and favouring the occurrence of new stages on patch succession. This process allows the colonization of species rare or absent from well-established communities, consequently enhancing richness and diversity values. The analysis of the turnover index corroborates this hypothesis, by indi- cating an increase in species gain tax for trampled plots until four months after trampling ceased.

It is well established that trampling may indirectly increase abundances of a range of common herbivores, as a result of cover reduction of dominant species (Povey and Keough, 1991; Keough and Quinn, 1998). In the present study, the decrease in I. bicolor cover percentage over time may be responsible for the increase in $C$. subrugosa densities, even though none of these processes were related to trampling impacts. During grazing, herbivores usually dislodge barnacle young recruits, reducing their 
survival rates and consequently affecting barnacle density values (Dayton, 1971; Safriel et al., 1994).

Recolonization of bare spaces in barnacle assemblages depended mainly on planktonical larvae recruitment, in contrast to mussels and algae species that present lateral movements or vegetative growth. This may amplify the impacts of herbivore grazing on barnacle populations.

In this study, although density increases of C. subrugosa were not related to trampling, higher levels of mollusk grazing may have been an important factor preventing recovery of $C$. bisinuatus populations after trampling.

Other patterns, such as those observed for H. nigra, L. adansoni and B. solisianus were probably related to the natural decrease of $I$. bicolor cover and density, since these species are strongly associated to the I. bicolor bed.

In general, results agree with previous trampling studies, suggesting that even low intensities of trampling may cause some impact on intertidal communities and recovery may take several years. In this study, effects of human trampling were mainly observed in C. bisinuatus population, that occur in the upper portion of the intertidal zone, remaining exposed to trampling during several hours. Moreover, C. bisinuatus recovery was not observed until the next vacation period (nine months after trampling ceased), which suggests that impacts from several years may be accumulative in heavily trampled rocky shores.

Management strategies should include isolation of sensitive areas, construction of boardwalks, visitor education and monitoring programmes. In Brazil, additional data obtained from experimental studies are necessary in order to achieve a better understanding of trampling impacts on rocky shore communities, especially in the highly populated southeastern Brazilian shores.

Acknowledgements - We thank $1^{\circ}$ Batalhão de Artilharia AntiAérea do Forte dos Andradas (the Brazilian Army) for allowing access to Obuseiro beach. We also thank M.T.V. Berardo, S. Bueno, M. Nomura and C. Nogueira, who helped during different phases of the research. This study was supported by a fellowship from CAPES.

\section{References}

BEAUCHAMP, KA. and GOWING, MM., 1982. A quantitative assessment of human trampling effects on a rocky intertidal community. Marine Environmental Research, vol. 7, no. 4, p. 279-293.

BROSNAN, DB. and CRUMRINE, LL., 1994. Effects of human trampling on marine rocky shore communities. Journal of Experimental Marine Biology and Ecology, vol. 177, no. 1, p. 79-97.

BROWN, PJ. and TAYLOR, RB., 1999. Effects of trampling by humans on animals inhabiting coralline algal turf in the rocky intertidal. Journal of Experimental Marine Biology and Ecology, vol. 235 , no. 1 , p. $45-53$.
CONNELL, JH., 1978. Diversity in tropical rain forests and coral reefs. Science, vol. 199, no. 4335, p. 1302-1310.

CONNELL, JH. and KEOUGH, MJ., 1985. Disturbance and patch dynamics of subtidal marine animals on hard substrata. In PICKETT, STA. and WHITE, PS. (Eds.). The ecology of natural disturbance and patch dynamics. New York: Academic Press.

DAYTON, PK., 1971. Competition, disturbance and community organization: the provision and subsequent utilization of space in a rocky intertidal community. Ecological Monographs, vol. 41, no. 4, p. 351-389.

Environmental Systems Research Institute - ESRI, 1999. ArcView GIS 3.2. Available from: <http://www.esri.com>. Access in: 15 de Maio de 2004.

FLETCHER, H. and FRID, CLJ., 1996. Impact and management of visitor pressure on rocky intertidal algal communities. Aquatic Conservation: Marine and Freshwater Ecosystems, vol. 6, no. 4, p. 287-297.

GIORDANO, F., 2001. Colonização de placas de fouling no estuário de Santos (Santos-SP): análises transicional e de sensibilidade complementando a abordagem baseada em recobrimentos específicos e diversidade. São Paulo: University of Sao Paulo. Tese de Doutorado.

GUREVITCH, J. and CHESTER Jr., ST., 1986. Analysis of repeated measures experiments. Ecology, vol. 67, no. 1, p. 251-255.

Kovach Computing Services - KCS, 2000. MVSP - Multivariate Statistical Package 3.12a. Available from: <http://kovcomp.co.uk>. Access in: 01 de Maio de 2004.

KEOUGH, MJ. and QUINN, GP., 1998. Effects of periodic disturbances from trampling on rocky intertidal algal beds. Ecological Applications, vol. 8, no. 1, p. 141-161.

LIDDLE, MJ., 1975. A selective review of the ecological effects of human trampling on natural ecosystems. Biological Conservation, vol. 7, no. 1, p. 17-36.

MARTINS, CM., 2000. Isognomon bicolor (C.B. Adams 1845) (Bivalvia: Isognomonidae): ocorrência nova, redescrição e anatomia descritiva e funcional. São Paulo: University of Sao Paulo. Tese de Doutorado.

PINN, EH. and RODGERS, M., 2005. The influence of visitors on intertidal biodiversity. Journal of the Marine Biological Association of the United Kingdom, vol. 85, no. 2, p. 263-268.

POVEY, A. and KEOUGH, MJ., 1991. Effects of trampling on plant and animal populations on rocky shores. Oikos, vol. 61, no. 3, p. $355-368$.

SAFRIEL, UN., EREZ, N. and KEASAR, T., 1994. How do limpets maintain barnacle-free submerged artificial surfaces? Bulletin of Marine Science, vol. 54, no. 1, p. 17-23.

SCHIEL, DR. and TAYLOR, DI., 1999. Effects of trampling on a rocky intertidal algal assemblage in southern New Zealand. Journal of Experimental Marine Biology and Ecology, vol. 235, no. 2, p. 213-235

SEED, R., 1996. Patterns of biodiversity in the macro-invertebrate fauna associated with mussel patches on rocky shores. Journal of the Marine Biological Association of the United Kingdom, vol. 76, no. 1, p. 203-210.

SPSS INC., 2003. SPSS 12.0 for Windows. Available from: $<$ http:// www.spss.com>. Access in: 01 de Maio de 2004.

STATSOFT INC., 2003. Statistica 6.1. Available from: $<$ http://www.statsoft.com>. Access in: 13 de Junho de 2004.

THOMPSON, RC., CROWE, TP. and HAWKINS, SJ., 2002. Rocky intertidal communities: past environmental changes, present status and predictions for the next 25 years. Environmental Conservation, vol. 29 , no. 2 , p. $168-191$ 